\title{
Priority areas of international activity as a growth driver of the beauty industry in the Rostov region
}

\author{
Yulia Osipova ${ }^{1 *}$, and Lyudmila Kazmina ${ }^{1}$ \\ ${ }^{1}$ Don State Technical University, Gagarina Sq., 1, Rostov-on-Don, 344000, Russia
}

\begin{abstract}
The present article is concerned with analysis of the current state and prospects for further development of international activity and its regions fostering the development of the beauty industry. It is emphasized that the beauty industry can become one of the priority areas of international activity of the regions. The authors propose solutions of issues of deficiently variable forms and types of international activity in the beauty industry. Special attention is paid to arrangement of exhibitions related to the beauty industry.
\end{abstract}

\section{Introduction}

International activity is a branch of economic activity that is conducted in the production, scientific and technical, educational spheres, export, import of goods and the entry of enterprises into the international market for mutually beneficial cooperation.

Today, international activity is one of the key factors and priority areas in development of the economy, both of whole countries and of its certain regions. It is reflected in activities on export and import of goods, capital, technologies, services, implementation of joint projects with other countries, and integration processes in various spheres. This is especially clearly reflected in the tertiary sector, where the beauty industry holds leading positions.

Among the main forms of international activity of the Russian regions, their international agreements should be distinguished as the most important form of activity outside the country, which is of great importance for economic, cultural, scientific development of the regions.

International activities can be classified by such criteria as: content (agreements including cooperation in certain areas - cultural, trade and economic, scientific and technical or tertiary); geographic location of a foreign partner (agreements with a partner in the near abroad, agreements with a partner in the far abroad); the status of a foreign partner; duration (short-term, long-term or permanent); the number of parties (bilateral or multilateral); the status of officials and government authorities.

Participation of the regions in international activities is currently presented in a variety of forms. The forms of international activity of the regions of the Russian Federation are

* Corresponding author: osipova_yulia@list.ru 
widespread and include official and unofficial trips, holding various kinds of conferences, seminars, master classes, round tables, symposiua, as well as arrangement and participating in international exhibitions and fairs. One of the examples of active regional international activity is the Rostov region.

Considering the advantageous physicogeographical location, the diverse sectoral structure of the region's economy, it can be noted that it is the tertiary sector, and specifically the beauty industry, that currently have a dynamic character of development.

Moreover, the Rostov region is characterized by broad geography of international cooperation and active foreign economic activity. The priority areas of international activity are strengthening of economic and humanitarian relationships, development of partnership relations with the CIS countries and cooperation with non-CIS countries; expansion of relations with diplomatic missions operating in the territory of the Russian Federation, working with Russian foreign missions, international financial and public organizations; foreign economic activity and efforts on attraction of foreign investment in the economy.

The main business partners of the region are Belarus, Turkey, Switzerland, China, Egypt, Bangladesh, Ukraine, Italy, with which close business economic and humanitarian ties are maintained as with a stable and prospective region of southern Russia. Interest in such a developing sector of the economy as the beauty industry should be especially noted.

About 20 various agreements in the spheres of trade, economic, scientific, technical, humanitarian cooperation are in force between the Government of the Rostov region and 9 foreign states, including: Armenia, Belarus, Vietnam, Germany, Italy, Kazakhstan, Ukraine, Finland, France.

For the moment, the 2019 - 2030 government-sanctioned program Economic Development and Innovative Economy, which in turn includes such subprograms as Enabling Environment for Attracting Investments in the Rostov Region, Development of Small and Medium-Sized Businesses in the Rostov Region, Development of International, Interregional Cooperation and Support for Export Activities in the Rostov Region, has been developed and approved in the Rostov Region.

One of the tasks is to enable environment for an increase of employment in small and medium-sized businesses, including individual entrepreneurs and self-employed citizens, as well as to enable environment for expanding forms of international cooperation and growth in exports of goods and services.

Considering general trends in development of international economic activity, the beauty industry can be one of the priority areas.

International specialized congresses, official and unofficial trips, holding various conferences, seminars, master classes, round tables, symposiua can be a driver in this process; arrangement and participation in international exhibitions and fairs should be especially noted.

The goal of the study is to identify the main directions of international activities of the regions in development of the beauty industry.

Based upon the target goal, the following tasks are to be completed: to identify development factors of international activity; to define the beauty industry; to consider geography of international events in the beauty industry; to provide insight into international activity in the beauty industry exemplified by the Rostov region and to identify growth areas in this activity.

\section{Background and methods}

The concept of this article is based on abstract theorems of scientific papers of such authors as M, Bhattacharya, L. E. Okafor, V.Pradeep [1], who considered the importance of international activity in development of the regional economy, and S. Nebojsa, D. Silvio, C. 
E. Cedrola [2], whose papers cover aspects of development of scientific research of small and medium-size enterprises in international markets.

Formation, history and intensive rate of development of the global beauty industry are considered in the papers of F.Perez, P. G. Jones [3], W. Luo [4], A.V. Menon [5], P. F. Perez [6].Experience of China, Malaysia, and New York is presented.

Studies of C.M. Costa, S. Mendonca [7], T. T.N. Nguyen [8], Y. L. Chun, Z.M. Laroche [9] consider issues and prospects for further development of the beauty industry.

For this study, the provisions of M. Gença, B. Öksüzb [10], N. M. Watanabe, J. Kim, J. Park [11], considering problems and prospects for merchandising of known worldwide beauty brands to the international market.

T. Klabikova Rabova [12] considers communications strategies of development of international activity in the beauty industry.

It should be noted that both mass culture and modern trends in development of the international cosmetics industry play key roles in development of the beauty industry. It is proved by the provisions of papers of C. Dambrin, C. Lambert [13]. C. H.Lee, E. Koa, H. Tikkanen, M. Cao, T. Phan, G. Aiello, R. Donvito, S. Raithel [14] argue that in today's context, international activity triggers shifts in customers' attitude toward beauty brands and brings them to the front in the international market. Such arguments are supported by C. Atanga, A.Francis, E.Amuquandoh, E. K. Amenumey [15], C. Anastasiadou, S. Vettese [16] in their papers.

When conducting the study, the authors also relied on the provisions of the works L.N. Kazmina, V.S. Makarenko, V.V. Provotorina, E.Shevchenko, G. Ekinil, A.Petrenko T.N. Grigorenko, [17-21].

In the study, the authors applied such research methods as a descriptive method used to characterize the current prospects for further development of the beauty industry; a statistical analysis, including identification and subsequent analysis of international activity in the beauty industry; a comparative analysis of geographical coverage of exhibitions in the world, in Russia and in its regions exemplified by the Rostov region; a prospective method, used to identify priorities and new forms of international activity being a growth driver of the beauty industry.

\section{Results}

Today, international activity includes many areas of the economy and society.

Considering the current state of the beauty industry in Russia, it should be noted that this sector of the economy is one of fast-moving and attractive for international companies.

At the same time, the beauty industry faces fierce competition. Successful development of enterprises belonging to this industry consists in introduction of innovations into their activities, in implementation of a competent marketing strategy, in correct promotion in social networks, in high-quality service, in active international activities.

The term of beauty industry is interpreted by scientists as a branch of the economy, the core of which is industrial production of cosmetic products and equipment for beauty salons and SPA centers, which does not contradict traditional use of the word "industry" reflected in explanatory dictionaries. However, the specificity of the beauty industry is that production of a significant part of cosmetics, and especially equipment, is inextricably connected with the sphere of its professional application. Beauty industry products intended for high-tech manipulations with a human body, often involving intrusion into the life of a body, require special professional training from the specialists who apply them.

The beauty industry is a tertiary sector that combines such areas as cosmetology, hairstyling, nail service, visage, permanent makeup, tatooing, SPA procedures, massage 
parlors, tanning studios, etc. Moreover, the beauty industry, in addition to beauty service businesses, includes the cosmetics and beauty equipment industries.

Thus, the beauty industry is not only services provided by beauty salons, but also hightech industrial production of cosmetics and equipment used in this area of activity.

In addition to the main and permanent participants, there are many organizations and enterprises that contribute to successful and full-scale functioning of the beauty industry. Such companies include:

- $\quad$ suppliers and manufacturers of various hair, nail, skin care products, etc .;

- manufacturers and suppliers of special equipment and furniture for salons, SPA rooms, etc.;

- $\quad$ architectural and design studios developing interior design for beauty industry enterprises;

- construction companies and firms engaged in renovation, finishing and furnishing of premises for salon activities; world;

- transport and logistics companies that deliver equipment, cosmetics around the

- $\quad$ schools, academies and training centers for training of specialists, from specialists to front line management;

- recruiting agencies;

- $\quad$ firms providing audit and legal services;

- professional and specialized publications (Season of Beauty, SPA management, GLmagazine and online magazines;

- annual exhibitions of salon equipment, cosmetics and furniture;

- advertising agencies engaged in strategic planning, development of marketing policies, corporate identity, advertising, website and others;

- consulting firms;

- companies engaged in development of software and programs for enterprises of the beauty industry.

According to the statistics provided by the Federal Service of State Statistics of Russia, services of the beauty industry ranks third in tertiary sector $(12 \%)$, trailing only vehicle maintenance $(31 \%)$ and construction and home renovation $(28 \%)$. These data are represented in Fig. 1. 


\section{Structure of the Russian service sector}

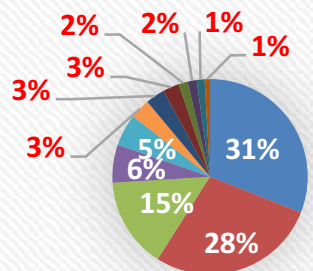

$\begin{array}{ll}\square \text { Vehicle maintenance } & \text { Construction and repair of housing } \\ \square \text { Beauty industry services } & \text { Funeral services } \\ \square \text { Repair of household appliances } & \text { Furniture manufacturing and repair } \\ \square \text { Repair and sewing of sewing products } & \text { Sauna services } \\ \square \text { Rental services } & \text { Photo studio services } \\ \square \text { Shoe repair and tailoring } & \text { Laundry services }\end{array}$

Fig. 1. Structure of the Russian service sector.

Currently, there are about 75,000 enterprises providing beauty services in the beauty industry in Russia. However, the statistical data does not reflect small individual entrepreneurs, the staff of which is no more than 3 people.

Today, in many regions of Russia, including the Rostov region, the beauty industry takes a leading position in the market of services for the population.

The most active participants in formation of the beauty industry are such cities as Moscow, St. Petersburg, Yekaterinburg, Rostov, Kazan and further, in decreasing order, almost all regions of Russia. Competition in these cities is increasing from year to year.

Without a question, such active development of this sector of the economy should be reflected in formation of priority areas of the investment policy in regions.

An interesting fact of active development of the beauty industry is the number of foreign investors who intend to invest in the Russian beauty business. In this situation, it is the active international activity that can be a growth factor of the beauty industry.

It is worth noting that for the present moment, services of the beauty industry are included in the block of public services. The main organizations that control activities of beauty enterprises are the Russian Consumer Protection Agency Rospotrebnadzor, which controls the sphere of public services, and Federal Supervisory Agency for Health Care Roszdravnadzor, which controls everything related to medical and cosmetic services.

In order to promote the beauty industry under free market conditions, to protect their interests in federal and regional authorities, in 2018, on the initiative of a number of enterprises, the All-Russian Public Organization "Association of Beauty Industry Professionals" was established.

Fo the present moment, the Association consolidates more than 1,500 large, medium and small business entities, non-for-profit organizations and beauty enterprises, individual entrepreneurs, self-employed citizens, organizations and enterprises of related and supporting areas (suppliers, media, educational institutions, etc.) from 60 regions of the country.

International activity in the area of the beauty industry develops quite rapidly. The number of exhibitions and conferences dedicated to "beautiful" business increases year on year. As a rule, these are specialized events attended by business owners, managers, and 
industry specialists. Within the framework of such events, professionals can gain a familiarity with the latest achievements and innovations in the area of the beauty industry.

The largest annual international events of beauty industry are presented in Table 1.

Table 1. Annual expected international events of the beauty industry in 2021.

\begin{tabular}{|c|c|c|c|c|}
\hline № & $\begin{array}{c}\text { Exhibition name } \\
\text { (events) }\end{array}$ & $\begin{array}{l}\text { Location of the event } \\
\text { (country, city) }\end{array}$ & $\begin{array}{c}\text { Dates of the } \\
\text { event }\end{array}$ & Venue \\
\hline 1. & Beauty Forum Leipzig & Germany, Leipzig & 17.04-18.04 & Leipzig Exhibition Centre \\
\hline 2. & Trends of Beauty - Graz & Austria, Graz & $17.04-18.04$ & Stadthalle Graz \\
\hline 3. & INTERCHARM professional & Russia, Moscow & 22.04- 24.04 & Crocus Expo IEC \\
\hline 4. & Beauty \& Style & Hungary, Budapest & $01.05-02.05$ & HUNGEXPO \\
\hline 5. & $\begin{array}{c}\text { International Lille Tattoo } \\
\text { Convention }\end{array}$ & France, Lille & 07.05- 09.05 & Lille Grand Palais \\
\hline 6. & China Beauty Expo / CBE & China, Shanghai & $12.05-14.05$ & $\begin{array}{c}\text { Shanghai New International } \\
\text { Expo Centre }\end{array}$ \\
\hline 7. & Siberian Beauty Week & Russia, Novosibirsk & $19.05-21.05$ & Novosibirsk Expocentre \\
\hline 8. & BEAUTY DUSSELDORF & Germany, Dusseldorf & $28.05-30.05$ & Messe Dusseldorf \\
\hline 9. & Top Hair International & Germany, Dusseldorf & $29.05-30.05$ & Messe Dusseldorf \\
\hline 10. & Moscow Tattoo Convention & Russia, Moscow & 29.05- 30.05 & $\begin{array}{l}\text { Sokolniki, Museum and } \\
\text { Educational Center }\end{array}$ \\
\hline 11. & $\begin{array}{c}\text { Kunming International Beauty } \\
\text { Expo }\end{array}$ & China, Kunming & 01.06- 03.06 & $\begin{array}{c}\text { Kunming International } \\
\text { Convention \& Exhibition Center }\end{array}$ \\
\hline 12. & LADY EXPO & Armenia, Yerevan & 04.06- 06.06 & $\begin{array}{l}\text { Yerevan EXPO, Exhibition } \\
\text { Complex }\end{array}$ \\
\hline 13. & COSMETIC BUSINESS & Germany, Munich & 09.06- 10.06 & $\begin{array}{c}\text { M.O.C, Events and Order } \\
\text { Center }\end{array}$ \\
\hline 14. & Cosmoprof North America & USA, Las Vegas & 27.06- 29.06 & $\begin{array}{l}\text { Mandalay Bay Convention } \\
\text { Center }\end{array}$ \\
\hline 15. & $\begin{array}{c}\text { PCE - Shanghai International } \\
\text { Personal Care Expo }\end{array}$ & China, Shanghai & 05.08- 07.08 & $\begin{array}{c}\text { Shanghai New International } \\
\text { Expo Centre }\end{array}$ \\
\hline 16. & IBE & Malaysia, Kuala Lumpur & 07.08- 10.08 & $\begin{array}{l}\text { Malaysia International Trade \& } \\
\text { Exhibition Centre (MITEC) }\end{array}$ \\
\hline 17. & $\begin{array}{c}\text { CENTRAL ASIA BEAUTY } \\
\text { EXPO }\end{array}$ & Kazakhstan, Alma-Ata & $11.08-13.08$ & Atakent, $\mathrm{KCDS}$ \\
\hline 18. & HKTDC Beauty \& Wellness Expo & China, Hong Kong & 12.08- 01.08 & $\begin{array}{l}\text { Hong Kong Convention \& } \\
\text { Exhibition Centre }\end{array}$ \\
\hline 19. & $\begin{array}{c}\text { CIHF - China International Hair } \\
\text { Fair }\end{array}$ & China, Guangzhou & 30.08- 01.09 & $\begin{array}{c}\text { Jinhan Exhibition Centre (Poly } \\
\text { World Trade Center) }\end{array}$ \\
\hline 20. & $\begin{array}{c}\text { Cosmoprof CBE ASEAN } \\
\text { Bangkok }\end{array}$ & Thailand, Bangkok & 06.09- 08.09 & $\begin{array}{c}\text { Impact Exhibition \& } \\
\text { Convention Center }\end{array}$ \\
\hline 21. & Cosmoprof & Italy, Bologna & $09.09-13.09$ & Bologna Exhibition Centre \\
\hline 22. & InterCHARM Korea & South Korea, Seoul & $15.09-17.09$ & COEX Korea Exhibition Center \\
\hline 23. & Beauty Expo & Kyrgyzstan, Bishkek & $16.09-18.09$ & KGIFK Arena \\
\hline 24. & BeautyExpo Uzbekistan & Uzbekistan, Tashkent & $16.09-18.09$ & $\begin{array}{l}\text { Kamolot, Palace of Youth } \\
\text { Creativity }\end{array}$ \\
\hline 25. & Beauty Trade special & Netherlands, Utrecht & $25.09-27.09$ & Jaarbeurs Utrecht \\
\hline 26. & Beautyworld Middle East & UAE, Dubai & $05.10-07.10$ & Dubai World Trade Centre \\
\hline 27. & CHARM-Profi & Russia, Samara & $07.10-10.10$ & Expo-Volga, VC \\
\hline 28. & I love me & Finland, Helsinki & $22.10-24.10$ & Helsinki Fair Centre \\
\hline 29. & Salon Look Internacional & Spain, Madrid & $22.10-24.10$ & IFEMA Feria de Madrid \\
\hline 30. & InterCHARM & Russia, Moscow & $27.10-30.10$ & Crocus Expo IEC \\
\hline 31. & Cosmoprof India & India, Mumbai & $28.10-30.10$ & $\begin{array}{c}\text { Bombay Exhibition Centre - } \\
\text { NSE Exhibition Complex }\end{array}$ \\
\hline 32. & Beauty Forum Munchen & Germany, Munich & $30.10-31.10$ & New Munich Trade Fair Centre \\
\hline 33. & COSMEX & Thailand, Bangkok & $02.11-04.11$ & $\begin{array}{c}\text { Bangkok International Trade \& } \\
\text { Exhibition Centre }\end{array}$ \\
\hline 34. & Beauty and Health & Russia, Saint Petersburg & $03.11-07.11$ & Eurasia, CVC \\
\hline 35. & SuluExpo & Kazakhstan, Nur-Sultan & $11.11-13.11$ & Korme, EC \\
\hline 36. & Allt for Halsan & Sweden, Stockholm & $12.11-14.11$ & $\begin{array}{l}\text { Stockholmsmassan Exhibition } \\
\text { and Convention Center }\end{array}$ \\
\hline 37. & Cosmoprof Asia & China, Hong Kong & $16.11-19.11$ & $\begin{array}{l}\text { Hong Kong Convention \& } \\
\text { Exhibition Centre }\end{array}$ \\
\hline 38. & Biolife & Italy, Bolzano & 18.11-21.11 & Fiera Bolzano \\
\hline
\end{tabular}

Analyzing the geography of annual international events of the beauty industry, it can be said that they are held in many countries of the world, Europe, Asia and America. As a rule, 
the agenda of such events is short-term and is scheduled for 2-3 days. However, it should be noted that such exhibitions do not have representatives of such large continents as South America and Africa. Australia is not a member either.

In the course of organization of international activities in this area, specialists not only gain a familiarity with the hottest new trends in the beauty industry, but also negotiate mutually beneficial contracts for supply or use of world famous brands of cosmetic products, salon and medical equipment, etc.

Moreover, special franchise programs are offered whereby leading beauty salons give entrepreneurs wishing to start salon business an opportunity to.

It should be noted that in the territory of Russia, all-Russian and regional annual events of the beauty industry with international participation of beauty specialists are held. The most famous of them are presented in Table 2.

Table 2. Annual expected regional events of the beauty industry in 2021 .

\begin{tabular}{|c|c|c|c|c|}
\hline № & Exhibition name (events) & $\begin{array}{l}\text { Location of the event } \\
\text { (country, city) }\end{array}$ & $\begin{array}{l}\text { Dates of } \\
\text { the event }\end{array}$ & Venue \\
\hline 1. & Charm. Rostov-on-Don & $\begin{array}{l}\text { Russia, Rostov-on- } \\
\text { Don }\end{array}$ & $\begin{array}{l}11.02- \\
14.02\end{array}$ & $\begin{array}{l}\text { DonExpocenter, } \\
\text { CEC }\end{array}$ \\
\hline 2. & Beauty and Health & $\begin{array}{c}\text { Russia, Saint } \\
\text { Petersburg }\end{array}$ & $\begin{array}{c}14.04- \\
18.04\end{array}$ & Eurasia, CEC \\
\hline 3. & Management of beauty salons & Russia, Moscow & $\begin{array}{c}22.04- \\
23.04\end{array}$ & Crocus Expo IEC \\
\hline 4. & IdealBeauty & Russia, Krasnoyarsk & $\begin{array}{l}29.04- \\
02.05\end{array}$ & Siberia, MVDC \\
\hline 5. & Days of beauty in Ufa & Russia, Ufa & $\begin{array}{l}12.05- \\
15.05\end{array}$ & VDNH-EXPO \\
\hline 6. & Siberian Beauty Week & Russia, Novosibirsk & $\begin{array}{l}19.05- \\
21.05\end{array}$ & Expocenter \\
\hline 7. & $\begin{array}{c}\text { Beauty-market - Beauty on } \\
\text { the Volga }\end{array}$ & Russia, Volgograd & $\begin{array}{l}20.05- \\
22.05\end{array}$ & Expocentre \\
\hline 8. & Beauty Show Krasnodar & Russia, Krasnodar & $\begin{array}{l}26.05- \\
28.05\end{array}$ & Expograd \\
\hline 9. & BeautyForum & $\begin{array}{c}\text { Russia, } \\
\text { Yekaterinburg }\end{array}$ & $\begin{array}{l}22.09- \\
24.09\end{array}$ & CMT \\
\hline 10. & Charm-Profi & Russia, Samara & $\begin{array}{l}07.10- \\
10.10\end{array}$ & Expo-Volga, EC \\
\hline 11. & Beauty and Health & $\begin{array}{c}\text { Russia, Saint } \\
\text { Petersburg }\end{array}$ & $\begin{array}{c}03.11- \\
07.11\end{array}$ & Eurasia, CVC \\
\hline 12. & Beauty and Health & Russia, Belgorod & $\begin{array}{l}10.11- \\
12.11\end{array}$ & $\begin{array}{l}\text { Belexpocenter, } \\
\text { ECC }\end{array}$ \\
\hline 13. & Beauty Industry & Russia, Chelyabinsk & $\begin{array}{l}11.11- \\
12.11\end{array}$ & CMT \\
\hline 14. & The world of style and beauty & Russia, Irkutsk & $\begin{array}{l}18.11- \\
21.11\end{array}$ & Sibexpocenter, EC \\
\hline
\end{tabular}

Out of 85 regions of Russia, such events are held only in 14, so it is necessary to recommend to expand the geography, to increase duration and to popularize beauty events by attracting not only specialists, but also residents and guests of the city.

Regional events of the beauty industry are held not only in Russia, but also in a number of countries such as Kazakhstan, where the SuluExpo regional exhibition is held annually, 
Kyrgyzstan - Beauty Expo, Uzbekistan - BeautyExpo Uzbekistan, Latvia - Baltic Beauty, Netherlands - Beauty Trade Special, Great Britain - Professional Beauty - North and Professional Beauty - London, UAE - Beautyworld Middle East, South Korea InterCHARM Korea, etc.

All the events presented promote international activities of the regions in general and the beauty industry in particular.

As a rule, within the framework of such events, specialists not only gain a familiarity with the hottest new trends in the beauty industry, but also negotiate mutually beneficial contracts. One of such examples is the Rostov region.

Today's statistics of state registration by type of economic activity showed that for the present moment there are 7,815 incorporated enterprises and more than 1,000 individual entrepreneurs in the beauty industry of the Rostov region, which is more than $10 \%$ of all enterprises of Russia. These figures indicate that this industry is on high demand in the region and the most developed.

In the Rostov region, the largest exhibition and fair platform in the South of Russia, the Congress \& Exhibition DonExpocentre, operates. During the year, more than 30 various thematic congresses, official and unofficial meetings, conferences, seminars, master classes, round tables, symposiua, as well as international exhibitions and fairs are held on its premises.

One of the largest exhibitions in the beauty industry is "Charm. Rostov-on-Don ".This exhibition is traditionally held in February on an annual basis. Within the framework of the event, such exhibit areas as Cosmetics and Perfumes, Medicine and Health, Makeup, Manicure and Pedicure, Beauty Salons, Hair Salons, SPA Services and related industries are presented. Exhibitors present products in the areas of cosmetology and aesthetic medicine, cosmetics for face and body care, pharmaceuticals, related products and accessories, optics, sun tanning parlors, etc.

This event is not only for informational purposes, but also contains educational aspects.Exhibition participants have an opportunity to take part in specialized seminars, master classes, round tables, symposiua and various competitive programs. Statistics show that the Charm. Rostov-on-Don beauty exhibition is annually visited by about 5000 professionals and interested people in 3 days. Charm. Rostov-on-Don can be considered as the first regional stage for professionals of the beauty industry of the Rostov region, as the dates precede the two largest international Russian exhibitions "INTERCHARM" Professional and "InterCHARM" which are traditionally held in Moscow at the end of April and October.

The list of international events in the beauty industry is to be expanded by working out new formats and development programs of both Russian and regional scale, covering all members of the Russian Federation and involving both specialists of this industry and a mass consumer of beauty services.

\section{Discussion}

The sector of tetiary, beauty salons and high-tech industrial production of cosmetics and equipment, united in the concept of the beauty industry, are one of the highly profitable modern sectors of the economy that increase at a rapid rate.

The expansion of international activities of regions is not only a growth driver of the beauty industry, but also a tool for generating employment and new opportunities for small and medium-sized businesses and self-employed persons, as well as attracting new investors, expanding forms of international cooperation and growth in exports of goods and services of the industry. 
The prospects for further development of the beauty industry urge active support not only at regional, but also at state level. Active development of this industry will also contribute to development of a large number of related industries and enterprises.

Analyzing the types of international activities in the beauty industry, the conclusion can be made that exhibition events are among the most popular all over the world at the moment.

So, for example, in 2021 alone, it is planned to hold about 38 largest international exhibitions, geographically held in all progressive countries and on all continents of the earth.

In addition to international events in the beauty industry, many countries, such as Kazakhstan, Kyrgyzstan, Uzbekistan, Latvia, the Netherlands, Great Britain, the United Arab Emirates, South Korea, etc. hold regional events.

It should also be noted that on the territory of Russia there are annual regional events of the beauty industry with the international participation of beauty specialists. The largest of them are "INTERCHARM professional" and "InterCHARM ", which are traditionally held in Moscow.

In the Rostov region, one of the largest beauty exhibitions is Charm. Rostov-onDon.This exhibition is traditionally held in February on an annual basis.Within the framework of the event, such exhibit areas as Cosmetics and Perfumes, Medicine and Health, Makeup, Manicure and Pedicure, Beauty Salons, Hair Salons, SPA Services and related industries are presented.

Thus, it can be said that the beauty industry has a dynamic character of development. Nevertheless, it is necessary to find new forms and expand the types of international activities that will contribute to promotion and popularization of this tertiary sector. Priority activities include the following:

- arrangement of specialized exhibitions and fairs (including within the framework of annual events such as Charm. Rostov-on-Don, Rostov the Hospitable, HoReCa. Don, World without Borders, etc.);

- carrying out such events as: Weeks of Beauty (of a city, farm, village), Festivals of hairdressing art, Festivals of nail service, Contests of beauty industry specialists, master classes (for both professionals and average consumers);

- establishment of the School of Beauty or Academy of Beauty;

- development and conducting of upgrade training courses with involvement of beauty industry masters of international level;

- arrangement of online exhibitions (for example, as a part of the Know Ours online exhibition);

- inviting masters of nail service, hairdressing and organizing master classes as part of city public events;

- holding conferences, congresses and forums with invitation of international beauty experts by organizing joint exhibitions and fairs with world famous cosmetic brands such as Schwarzkopf \& Henkel, L'Oreal, Procter \& Gamble, Unilever, Matrix , Londa Professional, Russian brands of ESTEL Professional, Ollin Professional in the territory of the Rostov region;

- holding specialized thematic events such as Week of Beauty (of a city, farm, village, stanitsa), Festivals of hairdressing, Festivals of nail service, Contests of beauty industry specialists;

- development and inclusion annual exhibitions and fairs of the beauty industry in the event calendar of the Rostov region;

- development and maintenance of the register of LLCs, individual entrepreneurs and self-employed persons in the beauty industry;

- popularization in the media and on the Internet; 
- placement of information about events in beauty salons, SPA-complexes, fitness clubs, etc.

It is necessary to develop a plan of the event calendar in the beauty industry that can become a basis for adoption of beauty industry development programs of each district in the Rostov region.

\section{Conclusions}

Thus, the conducted study of the analysis of international activity and identification of priority areas at the present stage of development of the beauty industry brings us to the following conclusions:

1. International activity can be considered as a driver for development of the beauty industry both in the world and in separate countries, and respectively in their regions.

2. Today, in many regions of Russia, including the Rostov region, the beauty industry takes a leading position in the market of services for the population. The most active participants in formation of the beauty industry are such cities as Moscow, St. Petersburg, Yekaterinburg, Rostov, Kazan and further almost all regions of Russia. Without a question, such active development of this sector of the economy should be reflected in formation of priority areas of the investment policy in regions.

3. The list of international events in the beauty industry is to be expanded by working out new formats and development programs of both Russian and regional scale, covering all members of the Russian Federation and involving both specialists of this industry and a mass consumer of beauty services.

4. Development of the beauty industry urges active legal support both at international and at regional level. It is necessary to develop draft bills and programs of comprehensive development of the beauty industry.

5. Considering international activity as a growth driver of the beauty industry, it can be said that the Rostov region has the necessary potential, which in the future can attract new investment flows to the region. Listed locations, events and ways to popularize international activity can become not only a promising growth driver of the beauty industry, but also have a positive effect on formation of priority areas of the investment policy in the region, and will also contribute to a rise in quality of life of local population and new job formation.

\section{References}

1. M. Bhattacharya, L. E. Okafor, V. Pradeep, Economic Modelling, 97, 1-13 (2021), doi.org/10.1016/j.econmod.2021.01.012

2. S. Nebojsa, S. Davcik, E. C. Cardinali, Journal of Business Research, 28, 650-660 (2021), doi.org/10.1016/j.jbusres.2020.04.042

3. F. Perez, G, Jones, Investigaciones De Historia Económica, 7(2), 334-335 (2010), doi.org/10.1016/j.ihe.2011.05.001

4. W. Luo, Women's Studies International Forum, 38, 1-10 (2013), doi.org/10.1016/j.wsif.2013.01.013

5. A. V. Menon, Poetics, 75, (2019), doi.org/10.1016/j.poetic.2019.02.005

6. P. F. Perez, Investigaciones de Historia Económica, 7 (2), 334-335(2011), doi.org/10.1016/j.ihe.2011.05.001

7. C. M. C. S. Mendonca, Research Policy, 48 (4), 968-982 (2019), doi.org/10.1016/j.respol.2018.10.026 
8. T. T. N. Nguyen, Heliyon, 6, (2020), doi.org/10.1016/j.heliyon.2020.e04887

9. Y. L. Chun, Z. M. Laroche, Journal of Retailing and Consumer Services, 50, 215-225 (2019), doi.org/10.1016/j.jretconser.2019.04.016

10. M. Gença, B. Öksüzb, Procedia Computer Science, 158, 745-750 (2019), doi.org/10.1016/j.procs.2019.09.110

11. N. M. Watanabe, J. Kim, J. Park, Journal of Retailing and Consumer Services, 58 (2021), doi.org/10.1016/j.jretconser.2020.102301

12. T. Klabikova Rabova, Procedia - Social and Behavioral Sciences, 12, 48-57 (2015), doi.org/10.1016/j.sbspro.2015.01.1173

13. C. Dambrin, C. Lambert, Management Accounting Research, 35, 35-36 (2017), doi.org/10.1016/j.mar.2016.03.003

14. C. H. Lee, .vito, S. Raithel, Journal of Business Research, 67 (10), 2155-2163 (2014), doi.org/10.1016/j.jbusres.2014.04.025

15. C. Atanga, A. F. E. Amuquandoh, E. K. Amenumey, Journal of Hospitality and Tourism Management, 31, 105-113 (2017), doi.org/10.1016/j.jhtm.2016.09.005

16. C. Anastasiadou, S. Vettese, Annals of Tourism Research, 89, (2021), doi.org/10.1016/j.annals.2021.103188

17. L. Kazmina, V. Makarenko, V. Provotorina, E. Shevchenko, E3S Web of Conferences, 175, 10001 (2020)

18. V. Provotorina, L. Kazmina, A. Petrenko, G Ekinil, E3S Web of Conferences, 175, 10002 (2020)

19. Ekinil, G., Provotorina, V., Petrenko, A., Gorgadze, L. E3S Web of Conferences, 217, 05006 (2020)

20. L. Kazmina, V. Makarenko, V. Provotorina, E. Shevchenko, E3S Web of Conferences, 210, 12002 (2020)

21. L. N. Kazmina, V. S. Makarenko, V. V. Provotorina, T. N. Grigorenko, International Journal of Economics and Business Administration, 7, 510-520 (2019), doi: $10.35808 / \mathrm{ijeba} / 297$ 